Ungminoridine is an optically inactive alkaloid and therefore the possibility is excluded that it is the racemate of zephyranthine [6]. The NMR spectrum was recorded on a JNM-4H-100/100 MHz instrument in deuterochloroform solution.

\title{
REFERENCES
}

1. M. Normatov, Kh. A. Abduazimov, and S. Yu. Yunusov, Uzb. khim. zh., no. 2, 25, 1965.

2. K. Kotera, Y. Hamada, K. Tori, K. Aono, and K. Kuriyama, Tetrah, Let., no. 18, $2009,1966$.

3. A. Hawksworth, P. W. Jeffs, B. K. Tidd, and T. P. Taube, J. Chem. Soc., 1981, 1965.

4. T. H. Kinstle, W. C. Wildman, and C. L. Brown, Tetrah. Let., no. 39, 4659, 1966.

5. R. Razakov, V. N. Bochkarev, N. S. Vul'fson, Kh. A. Abduazimov, and S. Yu. Yunusov, KhPS [Chemistry of Natural Compounds], 4, 227, 1968.

6. O. Shoji, RZhKhim, 6zh, 476, 1965.

27 February 1968

Institute of the Chemistry of Plant Substances AS UzSSR

UDC $547.944 / 945$

\section{STRUCTURE OF BUCHARAINE}

S. M. Sharafutdinova and S. Yu. Yunusov

Khimiya Prirodnykh Soedinenii, Vol. 4, No. 4, pp. 264-265, 1968

We have previousiy [1] established that the basic skeleton of bucharaine is 2, 4-dihydroxyquinoline. The structure of the side chain, which, according to our hypothesis, must be attached in the $\gamma$-position, remained undetermined.

The IR spectrum of chloroacetylbucharaine lacks the absorption band of a hydroxy group but has bands at 1740 and $1240 \mathrm{~cm}^{-1}$ which are characteristic for alcohol esters.

The production of chloroacetylbucharaine shows the presence of two hydroxy groups in bucharaine. The Kuhn-Roth oxidation of the latter gave acetone. The formation of acetone and the replacement of a hydroxy group by chlorine under the action of acetyl chloride in bucharaine confirms the presence in bucharaine of a $\mathrm{CH}_{3}-\mathrm{C}(\mathrm{OH})-\mathrm{CH} 3 \mathrm{grouping}$.

In view of the presence of one double bond, we ozonized bucharaine and isolated a bucharainic acid with the composition $\mathrm{C}_{17} \mathrm{H}_{21} \mathrm{O}_{6} \mathrm{~N}$, mp $288-289^{\circ} \mathrm{C}$, together with acetaldehyde. This shows that the double bond is located at the end of the chain in the form of the $\mathrm{CH}=\mathrm{CH}-\mathrm{CH}_{3}$ grouping. The nitrogen-free substance obtained by the hydrogenation of bucharaine [1] was oxidized by Percheron's method $[2,3]$. Of the oxidation products, acetic and valeric acids were identified by paper chromatography. The formation of valeric acid shows that the hydroxyisopropyl grouping is located on the fifth carbon atom of the side chain of bucharaine. The NMR spectrum of the substance has a doublet at $\delta=4.6$, $J=6 \mathrm{~Hz}$, with an intensity of two proton units and a quadruplet $(\delta=3.59)$ with an intensity of one proton unit, which may be due [4] to a $-\mathrm{CH}_{2}-\mathrm{CH}(\mathrm{OH})$ grouping. The position of the signal of the methylene group is characteristic for groups located next to an atom of oxygen which, in its turn, is attached to the nucleus [5].

On the basis of what has been said above, it may be concluded that bucharaine has the structure<smiles>CC=CCC(O)C(O)CCOC1=CC(=O)NC2C=CC=CC12</smiles>

\section{REFERENCES}

1. S. M. Sharafutdinova and S. Yu. Yunusov, KhPS [Chemistry of Nattural Compounds], no. 3, 1968.

2. F. Percheron and R. Goutarel, Bull. Soc. Chem. France, 10, 1198, 1957.

3. P. Kh. Yuldashev and S. Yu. Yunusov, DAN UzSSR, no, 6, 38, 1962.

4. K. Nukada, O. Xamamoto, M. Takeuchi, and M. Ohnichi, Anal. Chem., 35, 1892, 1963.

5. G. A. Kuznetsova, A. Z. Abyshev, M. E. Perel'son, Yu. N. Sheinker, and G. Yu. Pek, KhPS [Chemistry of Natural Compounds], 2, 310, 1966. 